\title{
EVALUATION OF AN IN-HOUSE SPECIFIC IMMUNOGLOBULIN G (IGG) AVIDITY ELISA FOR DISTINGUISHING RECENT PRIMARY FROM LONG-TERM HUMAN CYTOMEGALOVIRUS (HCMV) INFECTION
}

Silmara de SOUZA(1), Sandra H. A. BONON(2), Sandra C. B. COSTA(2) \& Cláudio L. ROSSI(1)

\begin{abstract}
SUMMARY
This article describes the standardization and evaluation of an in-house specific IgG avidity ELISA for distinguishing recent primary from long-term human cytomegalovirus (HCMV) infection. The test was standardized with the commercial kit ETI-CYTOK G Plus (Sorin Biomedica, Italy) using $8 \mathrm{M}$ urea in phosphate-buffered saline to dissociate low-avidity antibodies after the antigenantibody interaction. The performance of the in-house assay was compared to that of the commercial automated VIDAS CMV IgG avidity test (bioMérieux, France). Forty-nine sera, 24 from patients with a recent primary HCMV infection and 25 from patients with a long-term HCMV infection and a sustained persistence of specific IgM antibodies, were tested. Similar results were obtained with the two avidity methods. All 24 sera from patients with recently acquired infection had avidity indices compatible with acute HCMV infection by the VIDAS method, whereas with the in-house method, one serum sample had an equivocal result. In the 25 sera from patients with long-term infection, identical results were obtained with the two methods, with only one serum sample having an incompatible value. These findings suggest that our in-house avidity test could be a potentially useful tool for the immunodiagnosis of HCMV infection.
\end{abstract}

KEYWORDS: HCMV; Avidity test; Immunodiagnosis.

\section{INTRODUCTION}

Human cytomegalovirus (HCMV) is a member of the herpes family of viruses, which also includes herpes simplex virus, varicella-zoster virus, human herpes virus 6 and Epstein-Barr virus. Although HCMV has a world-wide distribution, infection with HCMV is more common in developing countries, particularly in areas with poor socioeconomic conditions $^{5,22}$. As with other herpesvirus infections, primary HCMV infection is followed by chronic infection or viral latency from which the virus may be reactivated ${ }^{21}$. Primary infection or reactivation of HCMV is usually either subclinical or self-limiting in immunocompetent persons $s^{5,12,18}$. However, in immunocompromised hosts such as organ transplant recipients, patients with cancer and individuals infected with human immunodeficiency virus (HIV), or in congenital infections, a significantly adverse clinical course and outcome is often seen ${ }^{18-22}$.

HCMV is the most common agent of viral intrauterine infection and affects $0.5-2.5 \%$ of all live births in different parts of the world ${ }^{1,10,19,20}$. In pregnant women, distinguishing the primary from non-primary HCMV infection is important, since the former is much more deleterious to the fetus than the latter ${ }^{22}$. This is also true for immunocompromised patients, in whom primary infections are often accompanied by symptoms whereas non-primary infection is usually asymptomatic ${ }^{14}$.
The diagnosis of recently acquired HCMV infection is usually based on the detection of specific immunoglobulin (Ig) M antibodies, seroconversion or a significant increase in specific $\mathrm{IgG}$ antibody concentrations. Since seroconversion, the most dependable serological marker, and a rise in $\mathrm{IgG}$ titres are seldom demonstrable, the detection of HCMV-specific IgM antibodies has been the most frequently used serological procedure for diagnosing acute infection. However, in some persons, IgM may be detected for many months following primary infection and may also be produced following reinfection or reactivation ${ }^{11,13,15,17,22}$. Moreover, false-positive HCMV results may occur with other herpesviruses and with some autoimmune disorders ${ }^{6,13,17}$.

Based on the observation that antibody avidity gradually increases after exposure to an immunogen ${ }^{8,23}$, several reports have shown that the avidity of IgG antibodies can be used as a marker for distinguishing recent primary from long-term infections, including HCMV infections $\mathrm{s}^{2-4,7,9,16}$.

In Brazil, commercial assays for evaluating the avidity of HCMVspecific IgG are expensive and are not readily available. The aim of this study was to standardize an economical in-house HCMV-enzyme-linked immunosorbent assay (ELISA) avidity test for routine use. To validate this in-house assay, its performance was compared with that of the

1) Departamento de Patologia Clínica, Faculdade de Ciências Médicas (FCM), Universidade Estadual de Campinas (Unicamp), C.P. 6111, 13083-970 Campinas, S.P., Brasil. (2) Departamento de Clínica Médica, FCM/Unicamp, Campinas, S.P., Brasil.

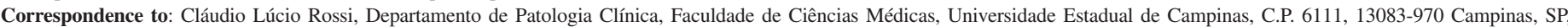
Brazil, Phone 55.19.3289 3273, Fax 55.19.3788 9434, e-mail: clr@fcm.unicamp.br 


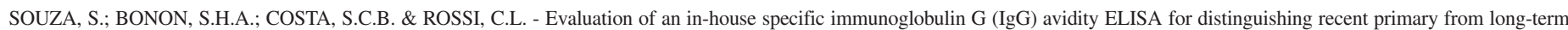
human cytomegalovirus (HCMV) infection. Rev. Inst. Med. trop. S. Paulo, 45(6):323-326, 2003.

commercial automated VIDAS CMV IgG avidity assay (bioMérieux, France), using well-characterized sera from patients with recent primary and long-term HCMV infections.

\section{MATERIALS AND METHODS}

Avidity tests: The in-house avidity assay was standardized using a commercial ELISA kit for detecting specific IgG antibodies (ETICYTOK-G Plus, Sorin Biomedica, Italy) modified to incorporate an elution step with urea to remove low-avidity antibodies from HCMV antigen. For the assay, $100 \mu \mathrm{l}$ of each serum diluted 1:101 were added to wells of polystyrene plates coated with HCMV antigen. All serum samples were run twice in duplicate. After incubation for $1 \mathrm{~h}$ at $37{ }^{\circ} \mathrm{C}$, the wells were washed four times with $0.15 \mathrm{M}$ phosphate-buffered saline, $\mathrm{pH} 7.2$ (PBS), and $100 \mu \mathrm{l}$ of $8 \mathrm{M}$ urea in PBS were added to two wells, whereas $100 \mu \mathrm{l}$ of PBS were added to the other two wells. After incubation for $5 \mathrm{~min}$ at room temperature and washing two times with PBS, $100 \mu \mathrm{l}$ of the optimal dilution of the conjugate in PBS were added to the wells. After a further $1 \mathrm{~h}$ incubation at $37^{\circ} \mathrm{C}$ and washing four times with PBS, $100 \mu \mathrm{l}$ of the substrate system (tetramethylbenzidine/hydrogen peroxide) were added to the wells. Thirty minutes after the addition of substrate, $100 \mu \mathrm{l}$ of $4 \mathrm{~N} \mathrm{H}_{2} \mathrm{SO}_{4}$ were added to each well to stop the reaction and the resulting absorbances were measured in an ELISA reader (Spectra SLT, SLT Instruments, Austria) at 450 and $405 \mathrm{~nm}$, with $620 \mathrm{~nm}$ used as the reference wavelength. The results obtained at $405 \mathrm{~nm}$ were used only when the reactions read at $450 \mathrm{~nm}$ had an O.D. higher than the linear range of the ELISA reader.

The avidity index was calculated as the mean absorbance of reactions in which the immune complexes were exposed to urea divided by the mean absorbance of reactions in which the immune complexes were not exposed to urea, expressed as a percentage. The run-to-run variation was determined by assaying an HCMV positive serum pool on five alternate days. On each day, the serum pool was tested in duplicate and the mean absorbance determined. The interassay CV was determined from the mean absorbance obtained in the five assays. The cut-off value was calculated using a modification of the $\mathrm{J}$ index ${ }^{24}$. The $\mathrm{J}$ index was calculated for avidity indices ranging from $30 \%$ to $70 \%$ at $5 \%$ intervals, using the formula: $\mathrm{J}=(\mathrm{a} / \mathrm{b})+(\mathrm{c} / \mathrm{d})-1$, where a is the number of sera with a compatible avidity index in the group of sera from patients with a recent infection, $b$ is the total number of sera from patients with a recent infection, $\mathrm{c}$ is the number of sera with a compatible avidity index in the group of sera from patients with a long-term infection and $\mathrm{d}$ is the total number of sera from patients with a long-term infection. Low and high avidity indices were defined based on the cut-off value and the interassay $\mathrm{CV}$.

The automated VIDAS system (bioMérieux, France) combines a twostep enzyme immunoassay sandwich method with a final fluorescent detection (ELFA). In the VIDAS CMV IgG assay, the results are expressed as a relative fluorescence value (RFV) and, in the absence of international units, as VIDAS arbitrary units (AU per milliliter). For the determination of avidity, two strips containing the reagents are used. In one strip a buffer containing $6 \mathrm{M}$ urea is used to elute low-avidity antibodies. In the other strip, which serves as the reference test, the buffer with urea is replaced by a wash buffer without urea. The avidity index is determined by calculating the ratio of the RFV result obtained for the sample with the strip containing urea relative to the RFV result obtained for the sample with the strip without urea. According to the manufacturer, an index $\geq 0.80$ excludes a recent primary infection of less than three months whereas an index $<0.8$ does not.

Patients and serum samples: The avidity tests were evaluated by testing sera from 24 patients with a recent primary HCMV infection and sera from 25 patients with a long-term HCMV infection and a sustained persistence ( $>1$ year) of specific IgM antibodies detected by ELISA. Serum HCMV-IgM and HCMV-IgG antibodies were determined using the automated VIDAS system (bioMérieux, France). Patients were diagnosed as having a recent HCMV infection based on serodiagnostic criteria: seroconversion (appearance of specific IgM and IgG antibodies in a previously seronegative patient) and/or detection of significant levels of specific IgM antibodies. All 24 patients in this group had clinical manifestations compatible with acute HCMV infection and the sera were collected in the first three months after the onset of the symptoms. All 25 patients with long-term HCMV infection had a well-documented history of pre-existing HCMV infection and the sera were collected no less than one year after the beginning of infection. Most $(n=20)$ of the sera in this latter group were from transplant recipients (13 renal, three liver, and four bone marrow).

\section{RESULTS}

Preliminary experiments with the in-house $\operatorname{IgG}$ avidity assay using varying concentrations of urea and different treatment times showed that a 5 min incubation step with $8 \mathrm{M}$ urea was the best combination for discriminating antibody avidities in patients with recent primary and long-term HCMV infections. The IgG avidity indices obtained with the in-house and VIDAS CMV methods for the sera from patients with recent primary and long-term HCMV infections are shown in Fig. 1.

The in-house avidity indices for the 24 acute-phase serum samples ranged from $10.3 \%$ to $52.1 \%$ (mean index $=29.5 \%$ ) whereas for the 25 serum samples from patients with a long-term infection, the indices ranged from $44.4 \%$ to $96.4 \%$ (mean index $=78.4 \%$ ). The highest $\mathrm{J}$ index was obtained with an avidity index of $55 \%$. Considering the interassay $\mathrm{CV}(4.9 \%)$, avidity indices $<50 \%$ and $>60 \%$ were considered indicative of recent and long-term HCMV infection, respectively. Based on this criterion $23(95.8 \%)$ of 24 sera from patients with a recent primary HCMV infection and $24(96 \%)$ of 25 sera from patients with a long-term infection had in-house avidity indices compatible with the stage of infection.

The VIDAS-CMV avidity indices for the 24 acute-phase sera ranged from 0.06 to 0.67 (mean index $=0.25$ ) whereas for the 25 serum samples from patients with a long-term infection, the indices ranged from 0.71 to 1 (mean index $=0.93$ ). According to the manufacturer, an index $\geq 0.80$ excludes a recent primary infection of less than 3 months whereas an index $<0.8$ does not.

Based on the criteria for interpreting avidity assays, divergent results were found in one acute-phase serum sample (avidity index $=52.1 \%$ ) with the in-house method and in one long-term serum sample with the in-house (avidity index $=44.4 \%$ ) and VIDAS (avidity index $=0.71$ ) methods. The long-term infection sample was taken 15 months after seroconversion from a patient who acquired primary HCMV infection after a renal transplant. 
(a) In-house avidity IgG ELISA avidity indices (\%)

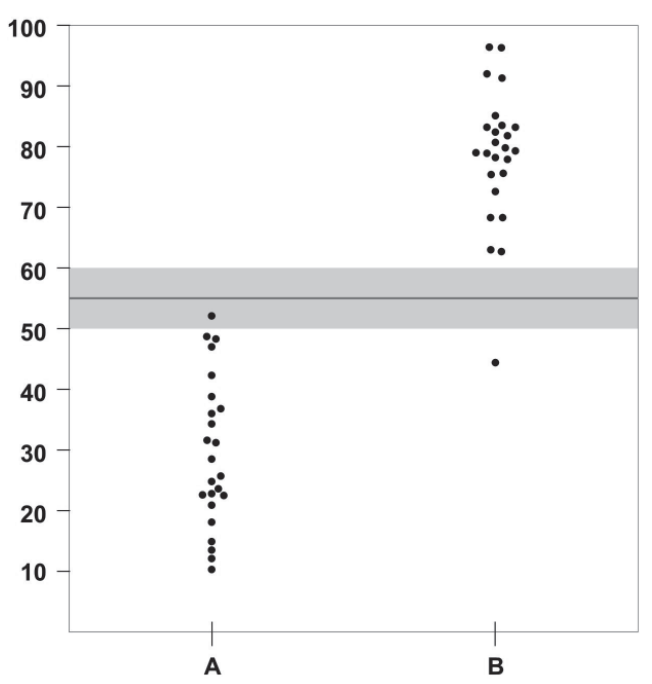

(b) VIDAS CMV IgG avidity indices (RFVu / RFVa)

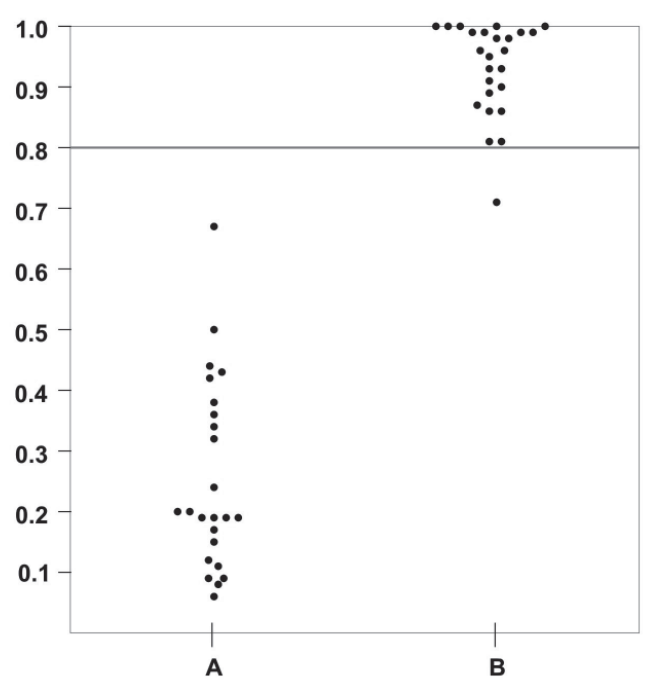

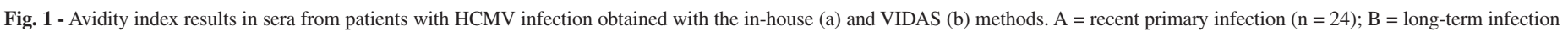

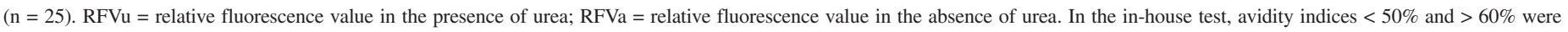

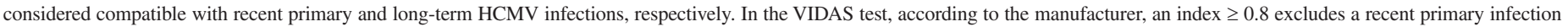
of less than 3 months whereas an index $<0.8$ does not.

\section{DISCUSSION}

HCMV is a serious, life-threatening opportunistic pathogen in immunocompromised persons, and is one of the principal causes of congenital malformations and neurological defects in infected neonates ${ }^{19-22}$.

The diagnosis of a recently acquired HCMV infection is usually based on the detection of specific IgM antibodies, seroconversion, or a four-fold or greater rise in the titre of HCMV-specific IgG antibodies. Since seroconversion and a rise in IgG titres are seldom demonstrable, the detection of HCMV-specific IgM antibodies has been the most frequently used serological marker for diagnosing acute infection. However, the use of tests with a low specificity and the persistence, in some patients, of specific IgM antibodies for a long time have led to the misdiagnosis of acute HCMV infection and unnecessary concern, especially with respect to pregnant women and immunocompromised patients. The determination of antibody avidity represents an important additional serological marker in the immunodiagnosis of several infections because low - and high-avidity antibodies occur predominantly in recent and long-term infections, respectively. The use of IgG avidity assays to confirm or exclude acute HCMV infection in cases of an IgMpositive result strengthens the serological diagnosis and could prevent unnecessary invasive procedures in numerous cases.

In this work, we standardized and evaluated an in-house specific IgG avidity ELISA for distinguishing recent primary from long-term HCMV infection. The performance of the in-house assay was compared with that of a commercial automated VIDAS CMV IgG avidity test. Forty-nine sera, 24 from patients with a recent primary HCMV infection and 25 from patients with a long-term HCMV infection with a sustained persistence of specific IgM antibodies, were tested. Similar results were obtained with the two avidity methods. All sera from the 24 patients with recently acquired infection had avidity indices compatible with acute HCMV infection by the VIDAS method, whereas with the in-house method, one serum sample had an equivocal result. In the 25 sera from patients with long-term infection, identical results were obtained with the two methods, with only one serum sample having an incompatible value. The avidity indices used to discriminate between low $(<50 \%)$ and high $(>60 \%) \operatorname{IgG}$ avidity in our in-house avidity assay were similar to values published by other investigators. BODÉUS et al. ${ }^{4}$, who used an avidity test with $8 \mathrm{M}$ urea as the dissociating agent to screen serum samples from patients with a recent primary or long-term HCMV infection, showed that an avidity index $<50 \%$ corresponded to a recent primary infection, whereas an avidity index $>65 \%$ was highly suggestive of a past infection. GRANGEOT-KEROS et al. ${ }^{9}$ also used an avidity test with $8 \mathrm{M}$ urea as the dissociating agent to screen serum samples from pregnant women in different stages of HCMV infection. These authors showed that sera from women with a past or secondary HCMV infection had an avidity index $>60 \%$, whereas most of the sera from women with HCMV primary infection had avidity index $<50 \%$. In a similar study, using $6 \mathrm{M}$ urea as dissociating agent, EGGERS et al. ${ }^{7}$ defined avidity indices of $<40 \%$ and $>60 \%$ as indicative of acute primary and past HCMV infection, respectively. In a study of sera from pregnant women who had recently seroconverted following primary HCMV infection (within four months of the last negative sample) and of sera from individuals with long-term HCMV infection, PRINCE \& LEBER $^{16}$ showed that $99 \%$ of the acute-phase serum samples had avidity indices $<50 \%$, whereas $96 \%$ of serum samples from persons with past infection had avidity indices $>60 \%$.

Variations in the ranges for low- and high-avidity antibodies are expected and are probably related to several factors, including patient heterogeneity, immune status at the time of blood collection, time of 


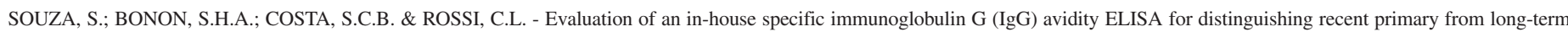
human cytomegalovirus (HCMV) infection. Rev. Inst. Med. trop. S. Paulo, 45(6):323-326, 2003.

blood sampling relative to the onset of infection, assay technique, antigen preparation, type and concentration of hydrogen bond-disrupting agent, and the method of calculating antibody avidity.

The results of this study suggest that our in-house avidity test may be a potentially useful tool for the immunodiagnosis of HCMV infections.

\section{RESUMO}

\section{Avaliação de um teste de avidez imunoenzimático para o citomegalovírus humano (ELISA-HCMV) para distinguir a infecção primária recente da infecção de longa duração}

Este artigo descreve a padronização e avaliação de um teste de avidez imunoenzimático para o citomegalovírus humano (ELISA-HCMV) para distinguir a infecção primária recente da infecção de longa duração. $\mathrm{O}$ teste foi padronizado com o kit comercial ETI-CYTOK G Plus (Sorin Biomedica, Itália), utilizando uréia $8 \mathrm{M}$ para a dissociação dos anticorpos de baixa avidez. A performance do teste ELISA-HCMV foi comparada com a do teste de avidez comercial automatizado VIDAS CMV IgG (bioMérieux, França), utilizando 24 soros de pacientes com infecção primária recente e 25 soros de pacientes com infecção de longa duração apresentando persistência de anticorpos específicos IgM. Resultados similares foram obtidos com os dois métodos de avidez. Todos os 24 soros de pacientes com infecção recentemente adquirida apresentaram índices de avidez compatíveis com infecção aguda pelo HCMV utilizando o teste VIDAS CMV IgG, enquanto que um dos soros apresentou resultado duvidoso no teste ELISA-HCMV. Os 25 soros de pacientes com infecção de longa duração apresentaram resultados idênticos com os dois métodos, com apenas um dos soros apresentando um valor não compatível. Estes resultados sugerem que o teste de avidez descrito pode ser potencialmente útil para o imunodiagnóstico da infecção pelo HCMV.

\section{ACKNOWLEDGEMENT}

Silmara de Souza was supported by a fellowship from Coordenação de Aperfeiçoamento do Ensino Superior (CAPES), Brazil.

\section{REFERENCES}

1. AZAM, A.Z.; VIAL, Y.; FAWER, C.L.; ZUFFEREY, J. \& HOHLFELD, P. - Prenatal diagnosis of congenital cytomegalovirus infection. Obstet. and Gynec., 97: 443448, 2001.

2. BLACKBURN, N.K.; BESSELAAR, T.G.; SCHOUB, B.D. \& O' CONNELL, K.F. Differentiation of primary cytomegalovirus infection from reactivation using the urea denaturation test for measuring antibody avidity. J. med. Virol., 33: 6-9, 1991.

3. BODÉUS, M.; BEULNÉ, D. \& GOUBAU, P. - Ability of three IgG-avidity assays to exclude recent cytomegalovirus infection. Europ. J. clin. Microbiol. infect. Dis., 20: $248-252,2001$

4. BODÉUS, M.; FEYDER, S. \& GOUBAU P. - Avidity of IgG antibodies distinguishes primary from non-primary cytomegalovirus infection in pregnant women. Clin. diagn. Virol., 9: 9-16, 1998.

5. DE JONG, M.D.; GALASSO, G.J.; GAZZARD, B. et al. - Summary of the II international symposium on cytomegalovirus. Antivir. Res., 39: 141-162, 1998.

6. DEYI, Y.M.; GOUBAU, P. \& BODÉUS, M. - False-positive IgM antibody tests for cytomegalovirus in patients with acute Epstein-Barr virus infection. Europ. J. clin. Microbiol. infect. Dis., 19: 557-560, 2000.
7. EGGERS, M.; BÄDER, U. \& ENDERS, G. - Combination of microneutralization and avidity assays: improved diagnosis of recent primary human cytomegalovirus infection in single serum sample of second trimester pregnancy. J. med. Virol., 60: 324-330, 2000 .

8. EISEN, H.N. \& SISKIND, G.W. - Variations in affinities of antibodies during the immune response. Biochemistry, 3: 996-1008, 1964.

9. GRANGEOT-KEROS, L.; MAYAUX, M.J.; LEBON, P. et al. - Value of cytomegalovirus (CMV) IgG avidity index for the diagnosis of primary CMV infection in pregnant women. J. infect. Dis., 175: 944-946, 1997.

10. HAGAY, Z.J.; BIRAN, G.; ORNOY, A. \& REECE, E.A. - Congenital cytomegalovirus infection: a long-standing problem still seeking a solution. Amer. J. Obstet. Gynec., 174: 241-245, 1996.

11. KANGRO, H.O.; GRIFFITHS, P.D.; HUBER, T.J. \& HEATH, R.B. - Specific IgM class antibody production following infection with cytomegalovirus. J. med. Virol., 10: 203-212, 1982.

12. KANO, Y. \& SHIOHARA, T. - Current understanding of cytomegalovirus infection in immunocompetent individuals. J. dermatol. Sci., 22: 196-204, 2000.

13. LAZZAROTTO, T.; BROJANAC, S.; MAINE, G.T. \& LANDINI, M.P. - Search for cytomegalovirus-specific immunoglobulin $\mathrm{M}$ : comparison between a new Western blot, conventional Western blot, and nine commercially available assays. Clin. diagn. Lab. Immunol., 4: 483-486, 1997.

14. LAZZAROTTO, T.; SPEZZACATENA, P.; PRADELli, P. et al. - Avidity of immunoglobulin $\mathrm{G}$ directed against human cytomegalovirus during primary and secondary infections in immunocompetent and immunocompromised subjects. Clin. diagn. Lab. Immunol., 4: 469-473, 1997.

15. PASS, R.F.; GRIFFITHS, P.D. \& AUGUST, A.M. - Antibody response to cytomegalovirus after renal transplantation: comparison of patients with primary and recurrent infections. J. infect. Dis., 147: 40-46, 1983.

16. PRINCE, H.E. \& LEBER, A.L. - Validation of an in-house assay for cytomegalovirus immunoglobulin G (CMV IgG) avidity and relationship of avidity to CMV IgM levels. Clin. diagn. Lab. Immunol., 9: 824-827, 2002.

17. RAWLINSON, W.D. - Broadsheet number 50: diagnosis of human cytomegalovirus infection and disease. Pathology, 31: 109-115, 1999.

18. SISSONS, J.G.P. \& CARMICHAEL, A.J. - Clinical aspects and management of cytomegalovirus infection. J. Infect., 44: 78-83, 2002.

19. STAGNO, S.; PASS, R.F.; CLOUD, G. et al. - Primary cytomegalovirus infection in pregnancy. Incidence, transmission to fetus, and clinical outcome. J. Amer. med. Ass., 256: 1904-1908, 1986.

20. STAGNO, S.; PASS, R.F.; DWORSKY, M.E. et al. - Congenital cytomegalovirus infection: the relative importance of primary and recurrent maternal infection. New Engl. J. Med., 306: 945-949, 1982.

21. SWEET, C. - The pathogenicity of cytomegalovirus. FEMS Microbiol. Rev., 23: 457 482, 1999.

22. VAN DE MEER, J.T.M.; DREW, W.L.; BOWDEN, R.A. et al. - Summary of the international consensus symposium on advances in the diagnosis, treatment and prophylaxis of cytomegalovirus infection. Antivir. Res., 32: 119-140, 1996.

23. WERBLIN, T.P.; KIM, Y.T.; QUAGLIATA, F. \& SISKIND, G.W. - Studies on the control of antibody synthesis. III. Changes in heterogeneity of antibody affinity during the course of the immune response. Immunology, 24: 477-492, 1973.

24. YOUDEN, W.J. - Index for rating diagnostic tests. Cancer, 3: 32-35, 1950.

Received: 17 June 2003

Accepted: 14 October 2003 